\title{
Re-examining a theology of reconciliation: What we learn from the Kairos Document and its pedagogical implications
}

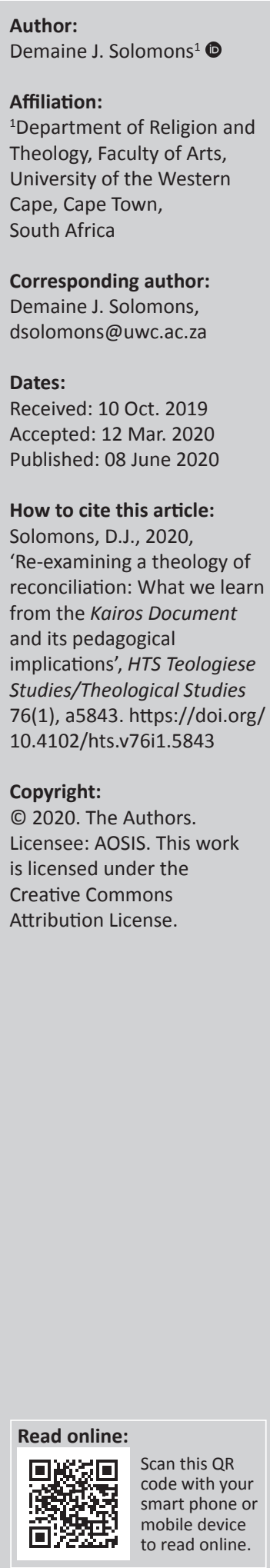

\begin{abstract}
This contribution is derived from a more extensive $2018 \mathrm{PhD}$ study in which the contested nature of the discourses on reconciliation is explored. It provides a conceptual analysis of how reconciliation is understood in the Kairos Document (1985). Regarded as an outstanding example of a theological response to the problem of apartheid, what is often overlooked is the tension implicit in its approach which, in turn, has serious implications for how matters of social justice are understood and acted upon. Here, the need for political, economic and cultural liberation is emphasised. It is assumed that social justice can only follow upon liberation, and that reconciliation is only possible on the basis of following justice. In this contribution, I contend that those who take this approach are confronted with the danger of self-secularisation, of reducing the Christian confession to nothing more than an example of religious affiliation that may be tolerated as long as its particular claims are not foregrounded. The obvious danger, as may be the case with the Kairos Document, is one of being socially relevant without having anything distinct to offer. This, in turn, has serious implications for how its history and significance are approached pedagogically.
\end{abstract}

Keywords: Reconciliation; Liberation; Justice; Kairos Document; South Africa.

\section{Setting the scene ${ }^{1}$}

The Truth and Reconciliation Commission (TRC) in South Africa is widely regarded as an organisation that was established to facilitate the transition from social conflict to a new dispensation. Frequently considered as the focal point of reconciliation, the TRC has enjoyed premier status in the context of South Africa's democratic transition. More recently, various forms of a TRC have been introduced to deal with similar social conflict in other parts of the world. ${ }^{2}$ Since its inception, the TRC has elicited much interest outside South Africa but is often criticised inside the country. Indeed, within the democratic context, the need for and the very symbol of national reconciliation remains highly contested. This has to be understood in terms of the years of struggle against apartheid. In the mid-1980s, the question that prevailed was whether political liberation for the oppressed black majority or reconciliation between black and white South Africans should have precedence. In the Kairos Document (1985), the emphasis on reconciliation at the expense of political liberation was severely criticised as a form of 'church theology'. Later during the country's transition to democracy (1990-1994), the need for a negotiated settlement became widely accepted. As part of such a settlement, the need to come to terms with the history and legacy of apartheid became evident. Both the experiences of the victims of apartheid and the gross violations of human rights by perpetrators simply needed to be addressed. The decision to establish the TRC followed upon these developments in 1994. This was soon supported by calls for 'national reconciliation', 'nation-building', the 'healing of memories', the rediscovery of humanity (Ubuntu) and a celebration of the so-called 'rainbow people of God' (see Tutu 1999). Nevertheless, as the proceedings of the TRC unfolded, there was a lot of criticism regarding the overarching emphasis on reconciliation (Jeffery 1999:157; Mamdani 1996:22-25, 2000:60; Soyinka 1999). These criticisms were related to various aspects of the process. Amongst other things, the very possibility of amnesty, the need for criminal justice, the objectivity of the commission, the understanding of 'truth', the emphasis on reconciliation, the leadership role of Anglican Archbishop Tutu, the associations with Christian symbolism, the need for compensation for the victims were some of the concerns raised (see Shore 2009).

1.For a detailed account of the contested nature of the reconciliation symbol between 1968 and 2010 , see Solomons (2018)

2.For a comparative study of different truth commissions around the world, see Hayner (2001). 
The TRC concluded its work in 1998, followed by a set of extensive reports. The legal aspects of the proceedings about amnesty and reparation need not be addressed here. Reflection on the legacy and significance of the commission has continued unabated since then. In this sense, the TRC cannot be reduced to a set of legal proceedings. It provided an opportunity for ordinary South Africans (who were neither victims nor perpetrators of gross violations of human rights) to reflect on their past and future through the publicity around the commission. Its significance, therefore, has to be understood in terms of calls for national reconciliation and the implications of that in various spheres of society. More than 20 years after the conclusion of its work, it is all too obvious that reconciliation between individuals and groups in South Africa remains a key priority. The South African Reconciliation Barometer of the Institute for Justice and Reconciliation (2013) gives a clear indication as to how South African citizens remain deeply divided especially when reflecting on the categories of race, class, ethnicity and culture.

Historically, the South African discourse over the symbol of national reconciliation cannot be separated from the influence of Christianity in the country. This has to be understood in terms of the allegiance to Christianity in South Africa, the use of the term 'reconciliation' in Christian soteriology and the significance of what is aptly described as the 'church struggle' against apartheid. The influence of Christianity is also evident with respect to the TRC. The pivotal role played by Archbishop Tutu, the charismatic chairperson of the TRC, is a prime example. In addition, one could also mention the leadership roles of several other church leaders (such as Alex Borraine, the deputy chairperson) and theologians (including Charles VillaVicencio and Piet Meiring). Indeed, the term 'reconciliation' was at the heart of the church struggle against apartheid. ${ }^{3}$ This is evident at least since the publication of the famous Message to the People of South Africa (1968). In the 1980s, the term was further used in conflicting ways in the Belhar Confession (1982/1986), the Kairos Document (1985) and the National Initiative for Reconciliation in 1985 - eliciting much controversy, especially in the Kairos Document (Conradie 2013:13). Therefore, while there may well be a general understanding in theological publications on the question of what 'reconciliation' entails, the controversies over the symbol of reconciliation suggest diverging interpretations of its significance for theological reflection. This gives credence to the idea that in the contemporary context reconciliation is best conceived as a contested concept, something lacking fixed or singular meaning (Doxtader 2009:12).

One should also note that 'reconciliation' is not merely a concept or metaphor but functions as a symbol with significant connotations. Like other religious symbols, it plays a powerful role in the social construction of reality, including the social transformation of reality. However, as Smit (1986:88) observed, the symbol of reconciliation is deeply tied up with ideological conflict in South Africa so 3. For a detailed account on how the term was used in the South African context in the 20th century, see De Gruchy (2002). that there is little agreement on its very meaning. Also, consider Smit's doubts over the potential of the symbol of reconciliation to transform society, because the term needs clarification, and the moment an idea needs clarification, it has already lost its power as a symbol - a symbol is precisely something that needs no explanation but is self-evident. It is for this reason that people (including the authors of the Kairos Document) often speak about 'true', 'real' or 'authentic' reconciliation, thereby implying that they reject some other kind of reconciliation, which may be considered 'cheap' or 'shallow'.

\section{The Kairos Document: An overview}

The Kairos Document (1985) (hereafter referred to as the document) consists of seven chapters. This includes a preface, five chapters, and a conclusion (see ed. Leonard 2010:37-80). ${ }^{4}$ In the preface, the authors define the document as 'a Christian, biblical and theological comment on the political crisis in South Africa today'. It is directed mainly at the churches and the broader Christian community - calling on them to reflect on the situation and to determine the most appropriate response given the situation in the country. Although not representing the views of any particular denominational body, individually or collectively, the authors recognise the responsibility of the churches to work towards dismantling apartheid, as well as contributing to the reconstruction of a society based on the principles of justice, democracy and peace. In this context, the document focuses on (1) the challenge directed at the churches and (2) addressing the urgent need to address this challenge. According to the authors of the document, the crisis dictates that the churches could no longer afford to ignore its responsibility. Here the crisis is located not only in the sociopolitical arena but also within the churches themselves. Although there is an acknowledgement of the many proclamations opposing apartheid coming from the churches, the document suggests that these responses lack the necessary urgency and effectiveness. Moreover, this ineffectiveness was because of existing theological suppositions that informed and governed the churches' responses. Accordingly, such suppositions lacked any semblance of social analyses as well as any real sense of 'an adequate understanding of politics and political strategy' to address the situation. On this point, the document (ed. Leonard 2010) states that:

Changing the structures of society is fundamentally a matter of politics. It requires a political strategy based on a clear social and political analysis. The Church has to address itself to these strategies and to the analysis upon which they are based. It is into this political situation that the Church has to bring the gospel. Not as an alternative solution to our problems as if the gospel provided us with a non-political solution to political problems. There is no specifically Christian solution. There will be a Christian way of approaching the political solutions, a Christian spirit and motivation and attitude. But there is no way of bypassing politics and political strategies. (p. 61)

4.The quotations in this section are all taken from the Kairos Document, see Leonard (2010:37-80) 
According to the authors, the reason for the inadequacies evident in the churches' response is because of the following factors: the first one is what the document refers to as 'State Theology'. It states that the apartheid state developed a theology of its own. This brand of theology (aptly referred to as 'State Theology') legitimised the politics of repression and violence against black people. Simply put, it is 'the theological justification of the status quo with its racism, capitalism and totalitarianism'. While 'State Theology' is claimed to be based on Romans 13:1-7, the document highlights the fact that the experience of the majority of South Africans suggests that the state is in fact not acting as a 'servant of God' for the benefit of the people. In fact, the opposite was believed to be true. The authors (ed. Leonard 2010) state:

If we wish to search the Bible for guidance in a situation where the State that is supposed to be 'the servant of God' betrays that calling and begins to serve Satan instead, then we can study Chapter 13 of the Book of Revelation. Here the Roman State becomes the servant of the dragon (the devil) and takes on the appearance of a horrible beast. (p. 51)

Furthermore, 'State Theology' claims to undergird the principle of 'law and order' in South Africa. However, in reality (ed. Leonard 2010):

$[T]$ his law is the unjust and discriminatory laws of apartheid and this order is the organized and institutionalized disorder of oppression. Anyone who wishes to change this law and this order is made to feel that they are lawless and disorderly. In other words, they are made to feel guilty of sin. (p. 51)

The document further states that the direct association of all those who oppose the apartheid state as being 'communists', and therefore by implication 'atheists', is problematic simply because most South Africans who have been active against apartheid are members of the churches and African religious traditions. The claim in the preamble of the South African Constitution, 'in humble submission to Almighty God', is thus denounced to be blasphemous. As a response, the document (ed. Leonard 2010) states:

[T] his god [referred to in the South African Constitution] is an idol. It is as mischievous, sinister and evil as any of the idols that the prophets of Israel had to contend with ... It is a god of superior weapons who conquered those who were armed within nothing but spears. It is the god of casspirs and hippos, the god of teargas, rubber bullets, sjamboks, prison cells and death sentences...the god of the South African State is not merely an idol or false god, it is the devil disguised as Almighty God - the antichrist. (p. 53).

The critique of 'State Theology' is followed by a section aptly referred to as 'Church Theology'. According to the document, 'Church Theology' is the 'type of faith and spirituality that has dominated church life for centuries'. The kind of faith and spirituality that undergirds 'Church theology' is described as 'other-worldly' - a theology with little concern for the affairs of the world. In this context, sociopolitical matters are seen to be worldly affairs that have very little to do with the spiritual concerns of the churches. The result is a situation where churches tend to rely solely on God to intervene and to put right what is wrong in the world. In turn, this leaves very little for human beings to do except pray for intervention. The document further suggests that this 'other-worldly' faith (and spirituality) is at the heart of the inadequate theological formulations perpetuated by the churches. As a result, the churches tend to resort to 'stock ideas', such as 'reconciliation', 'justice' and 'non-violence', to respond to the prevailing crisis. Here the problematic use of 'reconciliation' deserves special attention. The document (ed. Leonard 2010) states that:

There can be no doubt that our Christian faith commits us to work for true reconciliation and genuine peace. But as so many people, including Christians, have pointed out, there can be no true reconciliation and no genuine peace without justice. Any form of peace or reconciliation that allows the sin of injustice and oppression to continue is a false peace and counterfeit reconciliation. This kind of 'reconciliation' has nothing whatsoever to do with the Christian faith. (p. 55)

In this context, the churches were judged guilty in calling for reconciliation at all costs, thereby making it into an 'absolute principle that must be applied in all cases of conflict and dissension'. The insistence to call upon reconciliation and peace before injustices were removed was thus regarded to be 'unchristian' - a total betrayal of the Christian faith because it attempted to 'try and reconcile good and evil, God and the Devil'. For the authors of the document, 'no reconciliation is possible in South Africa without justice, without the total dismantling of apartheid'.

The document (ed. Leonard 2010) also raises important questions about the meaning of 'justice' as articulated by the churches when it states that:

$[T]$ he question we need to ask here, the very serious theological question is: What kind of justice? An examination of Church statements and pronouncements gives the distinct impression that the justice that is envisaged is the justice of reform, that is to say, a justice that is determined by the oppressor, by the white minority and that is offered to the people as a kind of concession. (p. 57)

In this context, any reform intent on not dismantling apartheid is seen to be less than adequate. For the authors of the document, it is a mere tactic to maintain political domination of black people. For the authors (ed. Leonard 2010):

[T]rue justice, God's justice, demands a radical change of structures. This can only come from below, from the oppressed themselves. God will bring about change through the oppressed as he did through the oppressed Hebrew slaves in Egypt. God does not bring his justice through reforms introduced by the Pharaohs of this world. (p. 58)

The document further comments on what is regarded to be the churches' overemphasis on 'non-violence' as a strategy to address injustice. The escalation of violence was indeed a contentious issue. Nevertheless, the authors of the document remain conscious that participation in the struggle for liberation meant that the issue concerning the use of violence needed to be addressed. At the same time, they also raised 
concern that calls for non-violent action were directed mainly at black people in the townships and not at the violence perpetrated by the apartheid state. As a response, they highlight the fact that throughout the Bible the word 'violence' is used to describe everything the wicked oppressor does and never to outline the activities of the oppressed in attempting to liberate themselves from aggression.

The section entitled 'Toward a Prophetic Theology' suggests that given the serious problems with 'State Theology' and 'Church Theology', the need to formulate new contextual theological paradigms arises. The document suggests that such a theological paradigm would have to take seriously, amongst others, the role of social and political analysis. According to them (ed. Leonard 2010):

$[A]$ prophetic response and a prophetic theology would include a reading of the signs of the times. This is what the great biblical prophets did in their times and this is what Jesus tells us to do. When the Pharisees and Sadducees ask for a sign from heaven, he tells them to 'read the signs of the times' (Matt 16:3) or to 'interpret the Kairos' (Lk 12:56). (p. 63)

Integral to 'reading the signs of the times' is the task of discerning what the root causes of the conflict are. For instance, the portrayal of the conflict as merely a 'racial war' was deemed misleading because it suggests two equal partners standing in opposition. The issue of race although a central feature of the conflict did not fully explain the situation. The two opposing groups are defined as one being the 'oppressor' and the other the 'oppressed'. This meant that the starting point for a 'Prophetic Theology' is the experience of people subjected to the oppression and tyranny. This is a central feature to what constitutes the prevailing crisis. The authors of the document, therefore, find it necessary to distinguish between those considered 'oppressors and the oppressed'. Accordingly, the (ed. Leonard 2010):

[O]ppressors are the people who knowingly or unknowingly represent a sinful cause and unjust interests. The oppressed are people who knowingly or unknowingly represent the opposite cause and interests, the cause of justice and freedom. Structurally in our society, these two causes are in conflict. (p. 66)

'Prophetic Theology' thus insists on not merely rehashing or repeating generalised Christian principles. Instead, the authors of the document call for a theology that responds to the particular concerns of the oppressed in the hands of an oppressive state. In this context, the churches (and Christians in particular) are challenged not to succumb to neutrality because, according to them, 'neutrality enables the status quo of oppression (and therefore violence) to continue. It is a way of giving tacit support to the oppressor'.

In the final section entitled, 'Challenge to Action', the authors shift attention to the need to end the endemic violence. They argue that it is not enough for Christians and churches to simply condemn apartheid, including its inherent violence. It is also not acceptable for churches to try to remain neutral or act as mediators between opposing groups. Rather, churches are called to unite in action in solidarity with those who are oppressed. This should be expressed through acts of 'civil disobedience'. In this context, civil disobedience represents the outward witness of defiance against apartheid. The authors further challenge the churches to address the racial divisions within their own ranks. The message is not merely that the churches lack integrity as the Body of Christ, but that such a division was the consequence of diverse sociopolitical persuasions and actions amongst church members, split along racial lines.

\section{The Kairos Document in perspective}

The publication of the document proved to be significant albeit also controversial. Its reception, as may have been expected, was not uniform. Some praised the document for its attempt to energise the vocabulary of political resistance. Others judged it to be politically dangerous and theologically suspect (Beyerhaus 1987; Borer 1998:121; Suggit 1987:70-74; Torrance 1986:42-45). The apartheid government responded immediately by detaining many who signed the document. They further dismissed supporters of the document, accusing them of being part of the anti-Christian revolutionary 'total onslaught', waged against South Africa - apparently, this was part of the government strategy to regain Christian legitimation and support within the English-speaking churches (De Gruchy 1995:108). For their part, the Dutch Reformed Church, the church that supported apartheid policies, declared its rejection, arguing that the document was the work of communists and heretics. Except for two churches, the document was never adopted by any of the churches to which it was primarily addressed (Van der Water 1998:28). ${ }^{5}$

Rejecting what was considered the 'liberal rhetoric of reconciliation', the document called for direct participation in the struggle for liberation. As mentioned above, this includes participating in acts of civil disobedience against the apartheid state. This was in contrast to the views of many white South Africans and church leaders who believed that they could be agents of reconciliation without actively engaging in the liberation struggle. Not only this, according to De Gruchy (2002):

[E]ven Churches and church leaders who had rejected apartheid and who were engaged in the struggle to end it, such as Archbishop Tutu, were unhappy about the way in which 'church theology' and reconciliation were, in their terms, caricatured and criticized. (p. 36)

\section{In addition (De Gruchy 2002):}

There was sharper criticism of the Kairos Document emanating from a circle of black theologians who remained faithful to the more radical concerns of the Black Consciousness movement. For them, the discourse of reconciliation was controlled by the 'ruling class' rather than by those who were alienated from whites, from the land, from the means of production, and thus from power. If reconciliation was to mean anything significant for them it will have to reverse this alienation. (p. 199)

According to Goba (1995:18), the reluctance of some black theologians to give their full support is attributed to the

5.The only two churches that officially adopted the Kairos Document were the Evangelical Presbyterian Church of Southern Africa who adopted it in 1985, and the United Congregational Church of Southern Africa, who adopted it in 1986. 
document's emphasis on social oppression in general terms, instead of a more specific focus on the racist foundations of apartheid. Mosala (1995), one of the foremost proponents of Black Theology, later remarked that:

The real hope of Black Theology in South Africa/Azania may well lie in the fact that it has never been co-opted by the Establishment. No Church has ever officially affirmed Black Theology as a legitimate and correct way of doing theology in South Africa ... This did not happen, and the situation was exacerbated by the Kairos Document's total neglect of Black and African theologies. In fact, many of us were incensed by the fact that this potentially empowering document was careful not to mention the word 'black' once - despite its Sowetan origins. (p. 81)

Notwithstanding the concerns raised, it was the critique of 'reconciliation' as a form of 'Church Theology' that attracted considerable attention. Amongst the most notable was Desmond Tutu who did not endorse the document, citing that it was not fair to the church or the New Testament rendering of reconciliation (eds. Botman \& Petersen 1997:113; Doxtader 2009:40). The main concern was the presupposition of liberation within the context of justice, repentance and forgiveness before reconciliation could be achieved. The authors (ed. Leonard 2010) argue that:

$[N]$ o reconciliation is possible in South Africa without justice. What this means in practice is that no reconciliation, no forgiveness and no negotiations are possible without repentance. The Biblical teaching on reconciliation and forgiveness makes it quite clear that nobody can be forgiven and reconciled with God unless he or she repents of their sins. Nor are we expected to forgive the unrepentant sinner. (p. 56)

In their view, good and evil cannot be reconciled because that would amount to a betrayal of the Christian faith. Göranzon (2010:53) suggests that this particular approach to reconciliation is likely informed by Black Theology. Here, Frostin's (1998) contribution on the place of reconciliation in Black Theology is particularly helpful. For the proponents of Black Theology, Frostin (1988:170-171) posits, the validity and value of the ministry of reconciliation are not in question. What is questioned, however, is the strategy on how to go about working towards this ideal. According to him (Frostin 1988):

Underlying much of the critique of Black Theology seems to be the notion that reconciliation can be brought about hinc et nunc provided that the conflicting parties have an open attitude. Black theologians, by contrast, argue that reconciliation between the oppressed and the oppressor is impossible as long as the oppressor insists on their privileged position. (pp. 170-171)

In this, Frostin identifies two distinct approaches to reconciliation - one is 'synchronic' and the other 'diachronic'. The synchronic approach to reconciliation suggests that mutuality can be achieved immediately by a change in mentality and attitude. In contrast, the diachronic approach suggests that reconciliation can only be arrived at as a result of the process through which the opposing parties are liberated from their different types of alienation. Thus, in the diachronic approach, the distinction between 'authentic' and 'cheap' reconciliation will often be made (Frostin 1988):

Underlying this distinction is the black analysis of apartheid as a state of oppression and injustice. In the context oppression, cheap reconciliation denotes a situation where the oppressor and the oppressed recognize and accept each other without questioning the roles each plays in the relationship determined by the structures of oppression. The structural analysis by Black Theology, by contrast, implies that metanoia is a necessary condition for authentic reconciliation. (p. 170)

Black theologians insist that the confession of sin is a necessary condition for reconciliation. Here, Frostin (1988:171) refers to the document when it states, 'no reconciliation, no forgiveness and no negotiations are possible without repentance'. This, however, does not mean that metanoia is not necessary for blacks, but merely that the call for repentance has different implications for both black and white people. Thus, the reconciliation in Black Theology (and by implication the Kairos Document) cannot be adequately understood if isolated from the truth claims of its social analysis. Moreover, the social analysis revealed that apartheid was a form of tyrannical oppression, not merely a race war. For the Kairos theologians, the state's espoused promise of legal equality was contradicted by its historical commitment to violence and oppression. This contradiction was proof that the apartheid 'regime has no moral legitimacy'. This was also taken as an explanation as to why God was not neutral in the struggle for liberation. According to Doxtader (2009:82), tied to the relative merits of revolutionary violence, the document redefined the idea of reconciliation. This was in sharp contrast to general calls for reconciliation, which was judged superficial and counter-productive. Moreover, what distinguished the document from other church-related statements is the way in which the central argument was constructed and performed. Its approach is counterintuitive, using reconciliation as a mode of opposition over and above its traditional usage - from that vantage point, the promise of reconciliation is radicalised.

In Doxtader's (2009:74) words, 'as such reconciliation [is] indeed not cheap, especially as its promise for the present depended on its abiding commitment to justice'. Accordingly, this commitment to justice contends that 'one side is right and the other wrong'. Reconciliation, thus, could not mean negotiation or compromise because tolerance beckoned 'false peace' and the perpetuation of 'evil', resulting in 'a total betrayal of all that the Christian faith has ever meant'. The authors of the document contend that, as the dominant theological discourse defined reconciliation in terms of personal guilt, it neglected to address injustice effectively, thus bolstering the claim of those supporting the theological justification of apartheid, that the present situation of separation expressed the will of God. Accusing the Dutch Reformed Church of heresy, the authors of the document argued that apartheid's perversion of reconciliation had to be returned to its theological foundations. This approach to reconciliation takes its inspiration from the burden of the 
cross. Theologically understood, this creates relationships between human beings and between humanity and God. In other words, as individuals concede their transgressions in the name of forgiveness, they provide an environment for collective action.

There is very little doubt that the document reflects a deep commitment to justice (and by implication liberation) in South Africa. However, in so doing, the authors of the document are often accused of giving primacy to justice at the expense of reconciliation (see Volf 2000:869-870). For some, the struggle for justice must not be regarded as an end itself but rather as a means to achieve reconciliation. However, based on the political situation in the country, the authors of the document may have underestimated how difficult this task would be. De Gruchy (2002) remarks that:

[T] he problem with the Kairos Document was that while it distinguished between cheap and costly reconciliation, it did not differentiate between various forms of justice even though it spoke clearly enough about justice in terms of God's reign. (pp. 199-200)

The fact that there is no coherent understanding of justice complicates the matter even further. Another concern is what Botman (2000:112) refers to as the document's focus on reconciliation, lacking a vision of how exactly the new nation will be established. In other words, the hope and promise articulated in the document must now be translated into concrete theological programmes for nation-building. This is closely aligned with Charles Villa-Vicencio's (1992) proposal for a theology of reconstruction, calling for a theology that is more than just oppositional, which, even though for good reason, the document appears to be. On the doctrine of reconciliation, Botman (2000:112-113) charges that the document lacks the Christological depth that is found in other church initiatives such as The Message to the People of South Africa (1968) or the Belhar Confession (1982/1986), for example. In his view, a stronger Christological emphasis would have clarified that God is not revealed anywhere else but in Jesus Christ. He believes this would have aided the document in providing something distinct, particularly regarding reconciliation's potential in the Christian tradition. In this sense, the document's narrow interest-based notion of theological irreconcilability is thus judged to be inadequate. In addressing the immediate challenge at hand, what the authors of the document may have overlooked is the tension implicit in its approach. This, in turn, has serious implications for how matters of social justice are understood and acted upon pedagogically.

\section{Pedagogical implications}

Taking the above into consideration, pedagogically one would have to reconsider how the document is generally understood - both in terms of teaching and future research. In this context, how do we reflect its significance, not just as an ethical concern (in a narrow sense) but something that is deeply theological? Put simply, how do we engage with it in ways that speak about the ethical as well as the theological significance of its being? Moreover, how would this translate to how this very important part of our history is taught at schools of theology - especially the way in terms of research, the Christian community can contribute to the discourse on reconciliation. On this point, the following aspects that have been further discussed may be worth considering.

It is important to highlight that the document and its associated tradition employ what Conradie (2013:17-21) refers to as an 'inductive' logic. According to this approach, the need for a wider frame of reference follows the argument that any breach in a relationship has wider implications than only for the two parties concerned. If such a breach has almost cosmic ramifications, the final resolution of such conflict has to take into account the widest possible scope of the problem. In this context, reconciliation between two individuals is only possible if the whole of that society is reconciled with itself. Ultimately, reconciliation between two individuals is possible only through reconciliation with God. Understandably, for apartheid South Africa the situation demanded an immediate remedy where the consequences of the problem were alleviated. Here it may be helpful but not enough to experience solidarity and companionship amidst suffering. In this sense, a victory of some sort is required. Here, the symbol of the cross, alone, is not enough because the victory has to be more than 'moral victory' or a new vision. For the authors of the document, apartheid and its associated evil had to be negated. In this context, victory may be ascribed to one's own efforts and commitment. Here the category of redemption is often used to capture the thrust of such salvific experiences. In the context of the South African struggle, one may speak about liberation from oppression and a victory over forces of destruction. Here the most important Christian symbol that may be used is the resurrection of Christ because it symbolises the power of God to address any situation and to conquer even death. In other words, it is a triumphal manifestation of God's decisive victory over the forces of evil. In this case, that victory is over the evil associated with but not exclusive to apartheid. In turn, this invites reflection on the cosmic scope of God's work of reconciliation. This would include not only human beings and human societies but also the whole created order - everything is included in God's work of reconciliation in Christ. Reconciliation should, therefore, be understood in the context of both God's work of creation and salvation. What is at stake is the tension between the Creator and the creature that has emerged because of captivity to the principalities and powers of this world (Col 1:18-23). In De Gruchy's (2002:53) words, 'God's cosmic reconciling activity precedes and provides the framework within which God's reconciliation of humanity occurs'. However, the main concern with this approach is the danger of self-secularisation, of reducing the Christian confession to nothing more than an example of religious affiliation that may be tolerated as long as its particular claims are not foregrounded. The obvious danger, as may be the case with the document, is one of being socially relevant without having anything distinct to offer in terms of its theology. 


\section{Acknowledgements}

This article has been derived from the author's PhD thesis, entitled 'Reconciliation as a controversial symbol: An analysis of a theological discourse between 1968-2010', submitted in fulfilment of the requirements for a joint degree of Doctor of Philosophy in the Faculty of Theology, Vrije Universiteit Amsterdam, and the Department of Religion and Theology, University of the Western Cape.

\section{Competing interests}

The author declares that he has no financial or personal relationships which may have inappropriately influenced him in writing this article.

\section{Author's contributions}

D.J.S. is the sole author of this research article.

\section{Ethical considerations}

This article followed all ethical standards for a research without direct contact with human or animal subjects.

\section{Funding information}

This research received no specific grant from any funding agency in the public, commercial or not-for-profit sectors.

\section{Data availability statement}

Data sharing is not applicable to this article as no new data were created or analysed during this study.

\section{Disclaimer}

The views and opinions expressed in this article are those of the author and do not necessarily reflect the official policy or position of any affiliated agency of the author.

\section{References}

Beyerhaus, P., 1987, The Kairos Document: Challenge or danger to the church?, Gospe Defence League, Cape Town.

Borer, T., 1998, Challenging the state: Churches as political actors in South Africa, 1980-1994, Notre Dame University Press, Notre Dame, IN.

Botman, H.R., 2000, 'The church partitioned or the church reconciled? South Africa's theological and historical dilemma', in W.E. Van Vught \& G.D. Cloete (eds.), Race and reconciliation in South Africa: A multicultural dialogue in comparative perspective, Lexington Books, Lanham, MD.
Botman, H.R. \& Petersen, R.M. (eds.), 1997, To remember and to heal: Theological and psychological reflections on truth and reconciliation, Human \& Rousseau, Cape Town.

Conradie, E.M., 2013, 'Reconciliation as one guiding vision for South Africa? Conceptual analysis and theological reflection', in E.M. Conradie (ed.), Reconciliation, a guiding vision for South Africa?, pp. 13-84, Sun Press, Stellenbosch.

De Gruchy, J.W., 1995, 'Christianity in twentieth-century South Africa', in M. Prozesky \& J.W. De Gruchy (eds.), Living faiths in South Africa, pp. 86-115, C. Hurst \& Co, London.

De Gruchy, J.W., 2002, Reconciliation: Restoring justice, SCM Press, London.

Doxtader, E., 2009, With faith in the works of words: The beginnings of reconciliation in South Africa, 1985-1995, David Philip, Cape Town.

Frostin, P., 1988, Liberation theology in Tanzania and South Africa: A first world interpretation, Lund University Press, Lund.

Goba, B., 1995, 'The role of religion in promoting democratic values in the postapartheid era: A personal reflection', Journal of Constructive Theology 1(1), 11-24.

Göranzon, A.B.O., 2010, 'The prophetic voice of the SACC after 1990 - Searching for a renewed Kairos', unpublished PhD thesis, University of the Free State.

Hayner, P., 2001, Unspeakable truths: Transitional justice and the challenge of truth commissions, Routledge, New York, NY.

Institute for Justice and Reconciliation, 2013, Confronting exclusion. Time for radical reconciliation. SA Reconciliation barometer survey: 2013 report, Institute for Justice and Reconciliation, Cape Town.

Jeffery, A., 1999, The truth about the Truth Commission, South African Institute for Race Relations, Johannesburg.

Leonard, G.S.D. (ed.), 2010, The moment of truth: The Kairos Documents, Ujamaa Centre for Biblical and Theological Community Development and Research, University of KwaZulu-Natal, Pietermaritzburg.

Mamdani, M., 1996, 'Reconciliation without justice', Southern African Review of Books, 46(1996), 3-5.

Mamdani, M., 2000, 'A diminished truth', in W. James \& L. Van de Vijver (eds.), After the TRC: Reflections on truth and reconciliation in South Africa, pp. 58-61, David Philip, Cape Town.

Mosala, I.J., 1995, 'Spirituality and struggle: African and black theologies', in C. VillaVicencio \& C. Niehaus (eds.), Many cultures, one nation: Festschrift for Beyers Naudé, pp. 79-89, Human \& Rousseau, Cape Town.

Shore, M., 2009, Religion and conflict resolution: Christianity and South Africa's Truth and Reconciliation Commission, Ashgate, Farnham.

Smit, D.J., 1986, 'The symbol of reconciliation and ideological conflict', in W.S. Vorster (ed.), Reconciliation and construction, pp. 79-112, University of South Africa Press, Pretoria.

Solomons, D.J., 2018, 'Reconciliation as a controversial symbol: An analysis of a theological discourse between 1968-2010', unpublished PhD thesis, University of the Western Cape.

Soyinka, W., 1999, The burden of memory, the muse of forgiveness, Oxford University Press, New York, NY.

Suggit, J., 1987, 'Kairos: The wrong way on the right road', Journal of Theology in Southern Africa 58, 70-74.

Torrance, J.B., 1986, 'South Africa today: The Kairos debate: Listening to its challenge', Journal of Theology of Southern Africa 55, 42-45.

Tutu, D.M., 1999, No future without forgiveness, Random House, London.

Van der Water, D.P., 1998, 'The legacy of a prophetic moment: A socio-theological study of the reception and response to the Kairos Document amongst churches, faith-communities and individuals in South Africa and within the international ecumenical community, focusing on the English-speaking churches in South Africa with special reference to the United Congregational Church of Southern Africa', $\mathrm{PhD}$ thesis, School of Theology, University of Natal.

Villa-Vicencio, C., 1992, A theology of reconstruction: Nation-building and human rights, Cambridge University Press, Cambridge.

Volf, M., 2000, 'Forgiveness, reconciliation, and justice: A theological contribution to a more peaceful social environment', Journal of International Studies 29(3), 861-877. https://doi.org/10.1177/0305829800029003060 